\title{
ANALISIS KAMPANYE PERILAKU HIDUP BERSIH DAN SEHAT UNTUK PENCEGAHAN PENULARAN COVID-19 OLEH PERGURUAN TINGGI DI MALANG RAYA
}

\author{
Megasari Noer Fatanti ${ }^{1}$, R. Zainal Fatah², Choiria Aggraini ${ }^{3}$
}

${ }^{1}$ Program Studi Pendidikan

Sosiologi, Fakultas IImu Sosial,

Universitas Negeri Malang

2Prodi Ilmu Administrasi Negara,

Fakultas Ilmu Administrasi,

Universitas Dr. Soetomo

Surabaya

${ }^{3}$ Program Studi Digital Public

Relations, Fakultas Komunikasi

dan Bisnis, Universitas Telkom

Jalan Semarang No. 5, Kota

Malang, Jawa Timur 65145

Correspondence:

R. Zainal Fatah rzainal@unitomo.ac.id

\begin{abstract}
The COVID-19 pandemic has caused a global health crisis, include Indonesia, as a impacted country. The effort to citizens is by learning from home. One of the activities affected is that lectures carried out online, but allowed strict health protocols. To support this policy, several universities in Malang City have issued policies both through official appeals and creative content on the university's official social media (Instagram). This study aims to analyze how the Clean and Healthy Lifestyle (PHBS) campaign practices are carried out by universities in Malang City to prevent the transmission of the COVID-19 virus. This research was conducted in qualitative and data will analyze descriptively. Data collection was collected by digital archive on Instagram accounts of several campuses in Malang City. The results of this study indicate that (1) the campaign by universities related to COVID-19 has not been massive and has not been evaluated properly; (2) message content on social media still contains general information related to COVID-19, it is not specifically; (3) the intensity of the PHBS campaign through social media has decreased since 2021. The conclusion is health campaigns related to COVID-19 must continue to be carried out by all universities in Malang City for resilience in facing the COVID-19 pandemic.
\end{abstract}

Keywords: COVID-19, Health Communication Campaign, PHBS, Social Media

\begin{abstract}
Abstrak: Pandemi COVID-19 menyebabkan krisis kesehatan global, temasuk Indonesia sebagai negara terdampak. Upaya perlindungan warga negara melalui belajar dari rumah. Aktivitasnya yakni perkuliahan daring dan protokol kesehatan ketat. Guna mendukung kebijakan tersebut, universitas di Kota Malang telah mengeluarkan kebijakan, himbauan resmi maupun konten kreatif di media sosial resmi universitas. Penelitian bertujuan menganalisis praktik kampanye Pola Hidup Bersih dan Sehat (PHBS) perguruan tinggi di Kota Malang dalam mencegah penularan virus COVID-19. Penelitian kualitatif deskriptif dengan metode pengumpulan data berupa studi arsip digital pada akun resmi (official account), instagram tiga perguruan tinggi di Kota Malang. Hasil penelitian menunjukkan (1) kampanye perguruan tinggi terkait COVID-19 belum massif dan terevaluasi dengan baik; (2) konten pesan di media sosial memuat informasi umum COVID-19, tidak spesifik; (3) intensitas kampanye PHBS media sosial semakin menurun awal tahun 2021. Kesimpulannya kampanye kesehatan COVID-19 dijalankan seluruh perguruan tinggi di Kota Malang agar sivitas akademika memiliki ketangguhan dalam menghadapi pandemi COVID-19.
\end{abstract}

Kata Kunci: COVID-19; kampanye komunikasi kesehatan; media sosial; perilaku hidup bersih dan sehat (PHBS) 


\section{1| PENDAHULUAN}

Sudah hampir 1.5 tahun masyarakat Indonesia, bahkan di seluruh dunia mengalami perubahan pola kehidupan sebagai akibat dari pandemi global COVID-19. Berawal dari penemuan Novel Coronavirus Disease (selanjutnya disebut COVID-19) di Kota Wuhan, ibukota Provinsi Hubei, China, tercatat jumlah korban yang terinfeksi mencapai 179 juta jiwa, dengan angka kematian mencapai 3.87 juta jiwa. Hingga artikel ini ditulis, Indonesia mencatat sejumlah 2 juta konfirmasi kasus positif dan 54.956 kasus kematian. Angka ini terus bertambah setiap hari, terlebih dari hasil whole genome sequencing (WGS) oleh peneliti di Pusat Penelitian Biologi LIPI menyebutkan bahwa varian delta (delta strain) yang dikenal memiliki tingkat penularan lebih cepat dari pendahulunya telah masuk ke beberapa daerah di Indonesia, seperti Jawa Barat dan Jawa Tengah (Aprillia, 2021).

Tidak dapat dipungkiri bahwa pandemi COVID-19 ini berhasil menghancurkan berbagai sektor kehidupan, seperti kesehatan, ekonomi, sosial, dan pendidikan. Berdasarkan rekomendasi ahli dengan mengedepankan keselamatan masyarakat, pemerintah akhirnya mengeluarkan kebijakan bekerja dari rumah (work from home/WfH) dan sekolah dari rumah (school from home/SfH) pada bulan Maret 2020, dan yang terbaru yaitu Pemberlakuan Pembatasan Kegiatan Masyarakat (PPKM) dimulai pada bulan Februari tahun 2021. Sejalan dengan itu, pemerintah juga meningkatkan pengawasan terhadap praktik pembatasan sosial (social distancing) dan pembatasan jarak secara fisik (physical distancing) yang tentunya membawa implikasi pada era kenormalan baru (Muliati, 2020; Nalini, 2021; Rizal, 2020; Supanji, 2021).

Dengan mengacu pada Surat Edaran Kemendikbud bulan Maret 2020 tentang sekolah dari rumah (school from home/SfH) membawa implikasi pada pembatasan aktivitas seperti perubahan metode pembelajaran dan perkuliahan secara daring (dalam jaringan) hingga penutupan kampus secara mendadak. Kondisi tersebut juga terjadi pada seluruh perguruan tinggi di Kota Malang sejak Maret 2020. Sebagai kota pendidikan, beberapa perguruan tinggi seperti Universitas Negeri Malang, Universitas Brawijaya, dan Universitas Islam Negeri (UIN) Maliki merespons perubahan aktivitas ini dengan menerbitkan beberapa himbauan terkait penerapan protokol kesehatan (3M dan 5M), penerbitan edaran tentang Pengaturan Terbatas Aktivitas Kampus (PTAK), kampanye sosial untuk meningkatkan kewaspadaan terkait pencegahan penularan COVID-19, hingga aktif memberikan edukasi terkait COVID-19 melalui radio, televisi lokal, dan surat kabar harian. Keterbatasan kegiatan di luar rumah menjadi mengalihkan kegiatan ke dalam media sosial maupun penggunaan media berbasis teknologi lainnya. Dah hal ini membawa dampak kepanikan terhadap penguunaan media atas akses informasi yang berkaitan dengan covid 19 . (Setiyaningsih, 2020).

Penelitian ini memfokuskan pada bagaimana perguruan tinggi di Kota Malang mengkampanyekan kewaspadaan terhadap COVID-19 melalui Perilaku Hidup Bersih dan Sehat (PHBS) yang dimuat dalam laman dan akun resmi media sosial masing-masing perguruan tinggi. Sebagai sektor yang paling terdampak dari pandemi COVID-19 ini, perguruan tinggi memiliki tanggung jawab untuk mensosialisasikan perubahan perilaku hidup bersih dan sehat sebagai bagian dari strategi pencegahan penularan virus. Seperti yang kita ketahui bahwa kampanye komunikasi kesehatan telah memberikan kontribusi penting bagi kemajuan penelitian tentang kesehatan masyarakat secara global dan dianggap sebagai dimensi penting dari upaya intervensi perubahan perilaku individu atau masyarakat, seperti pencegahan kanker dan penggunaan tembakau (Department of Health and Human Services., 2014; Medicine, 2002; NCI., 2008). Mengutip penelitian terdahulu disebutkan bahwa kampanye komunikasi kesehatan yang menggabungkan konsep pemasaran sosial pertama kali digunakan dalam program kampanye keluarga berencana (KB) dengan fokus pesan pada promosi penggunaan alat kontrasepsi pernah berhasil dilakukan pada tahun 1960-an di Amerika Serikat (Binnendijk, 1996; Mendelsohn, 1976). Melalui model kampanye tersebut, pesan yang disampaikan dapat mempengaruhi pengetahuan, 
kesadaran, dan norma sosial serta membantu mengubah perilaku kesehatan bagi individu maupun kelompok.

Komunitas menjadi sasaran dari PHBS, misalnya ada di komunitas panti asuhan dalam penelitian Sari et al., (2021), kegiatan pendampingan dilakukan untuk pemantauan pola hidup bersih dan sehat yang dilakukan oleh pengasuh panti atau dari anak asuh yang sudah remaja. Anggota yang lebih besar mengajari dan membimbing anggota di bawahnya agar dapat konsisten melaksanakan pola hidup bersih dan sehat, sehingga dapat membantu anak-anak panti asuhan untuk dapat menambah wawasan dan keterampilan untuk meningkatkan hidup sehat dan terhindar dari penularan Covid-19. Untuk lebih efektif karena pembatas aktifitas di masa pandemi, kampanye online dilakukan melalui media website (Setiyaningsih \& Jatmikowati, 2019). Sasarannya adalah anak muda dengan menggunakan website untuk mengkonsumsi makana sehat agar tercipta hidup yang sehat dan bersih (Suminar, \& Islami, 2021). Karena dalam Triono \& Setiyaningsih, (2017) konten dalam website mampu mempengaruhi perilaku dan membentuk desain komunikasi dalam setiap individu.

Sedangkan menurut Rokhaniyah \& Sinta, (2021) penguatan ketahanan masyarakat hari ini adalah melalui pembiasaan hidp bersi dan sehat agar terhindar dari penularan covid 19. Sedangkan gambaran umum mengenai perilaku hidup sehat dan bersih dimana persentase Perilaku Hidup Bersih dan Sehat (PHBS) pada masa pandemi Covid-19 pada mahasiswa yaitu sebanyak 49,2\% - 53,1\%. Persentase Perilaku Hidup Bersih dan Sehat pada usia anak yaitu sebanyak 50\% - 86,49\%. Dalam Asharo et al., (2021), efektifitas kampanye yang dapat terukur dengan baik adalah pelaksanaan kampanye di sekolah. Hal ini dikarenakan sistem sudah terbentuk dan kecenderungan peserta didik dalam mematuhi aturan sekolah adalah tinggi. Sehingga hal tersebut yang membuat kampanye di sekolah lebih efektif bilsa dibandingkan di tempat lainnya.

Keberhasilan kampanye juga ditentukan oleh media komunikasi informasi dan edukasi (KIE), seperti yang ada di Kabupaten Malang kampanye sehat untuk pekerja seks komersial melalui media KIE berhasil menurunkan resiko penularan penyakit (Setiyaningsih, 2017). Dalam Dari berbagai model kampanye, peneliti memilih model kampanye komunikasi kesehatan strategis yang digagas oleh Maibach, Kreps, dan Bonaguro pada tahun 1993. Dalam model ini terdapat empat prinsip dasar untuk mengukur secara kualitatif praktik kampanye tersebut sudah tepat atau belum Keempat prinsip menurut Cheng et al., (2011) meliputi (1) mengindentifikasikan tujuan kampanye; (2) mengembangkan strategi perumusan pesan; (3) pemilihan saluran/media yang tepat; dan (4) melakukan evaluasi serta re-orientasi pelaksanaan kampanye. Model kampanye ini memiliki tahapan yang lengkap dan jelas sehingga dapat dijadikan sebagai referensi dalam merancang sebuah kampanye sosial, terutama dibidang kesehatan. Untuk dapat menjawab rumusan masalah penelitian, maka riset ini mengarahkan pada aktivitas kampanye yang memuat pesan tentang pencegahan penularan virus COVID-19 melalui Perilaku Hidup Bersih dan Sehat yang disampaikan melalui laman dan akun media sosial resmi milik tiga perguruan tinggi di Kota Malang, yaitu Universitas Negeri Malang, Universitas Brawijaya, dan UIN Maliki Malang. Alasan peneliti memilih tiga universitas tersebut ditinjau dari jumlah fakultas, jumlah mahasiswa, dan keaktifan pihak kampus melakukan kampanye terkait COVID-19 di akun resmi media sosial milik Universitas. Tujuan penelitian untuk mengevaluasi sejauhmana praktik kampanye komunikasi kesehatan yang dilakukan oleh tiga perguruan tinggi di Kota Malang.

\section{2 | METODE PENELITIAN}

Metode penelitian merupakan cara kerja untuk memahami objek yang menjadi sasaran penelitian. Dalam hal ini, metode penelitian digunakan untuk menuntun peneliti dalam rangka kegiatan penelitian mengenai aktivitas kampanye Perilaku Hidup Bersih dan Sehat (PHBS) yang 
dilakukan melalui situs dan akun resmi media sosial oleh tiga Perguruan Tinggi di Kota Malang agar penelitian dapat dilakukan secara sistematis dan memperoleh hasil yang objektif. Berdasarkan pokok permasalahan yang telah diuraikan sebelumnya, maka pendekatan penelitian yang digunakan dalam riset ini yaitu pendekatan kualitatif Riset kualitatif bertujuan untuk memahami fenomena yang dialami oleh subyek penelitian secara holistik, mendalam, dan detail. Alasan peneliti memilih pendekatan kualitatif agar supaya konteks permasalahan dapat dipahami secara lebih mendalam dan menyeluruh, khususnya terkait praktik kampanye PHBS yang dilakukan oleh tiga perguruan tinggi di Kota Malang. Harapan peneliti yaitu dengan menggunakan pendekatan ini dapat diketahui bagaimana praktik kampanye PHBS dipraktikkan berdasarkan model kampanye komunikasi kesehatan strategis (MK3S).

Jenis penelitian dibagi menjadi dua macam, yaitu: a) berdasarkan manfaat, penelitian ini termasuk dalam riset praktis hasil penelitian diarahkan untuk dapat memberikan rekomendasi bagi perguruan tinggi yang melakukan kampanye komunikasi kesehatan terkait pandemi COVID-19; b) berdasarkan tujuan, penelitian ini termasuk dalam penelitian deskriptif yang mana tujuannya untuk eksplorasi dan klarifikasi mengenai suatu fenomena atau realitas sosial dengan cara mendeskripsikan sejumlah variabel yang berkenaan dengan masalah dan unit yang diteliti (Faisal, 2003).

Peneliti memilih jenis deksriptif dengan model cross sectional, alasannya yaitu karena penelitian ini dilakukan dalam waktu tertentu dan hanya dalam sekali waktu saja, dan tidak akan melakukan penelitian lain di waktu yang berbeda untuk dijadikan perbandingan (Sugiyono, 2017). Untuk dapat menghasilkan riset yang objektif, penelitian ini menggunakan studi dokumen sebagai teknik pengumpulan data utama. Awalnya, peneliti merancang untuk dapat melakukan observasi partisipan dan wawancara dengan berbagai pihak terkait seperti Satgas COVID-19 di ketiga universitas dan staf humas universitas, namun mempertimbangkan kondisi pandemi yang belum juga membaik, sehingga peneliti memutuskan untuk melakukan observasi secara digital melalui akun resmi media sosial ketiga perguruan tinggi yang dipilih.

Adapun fokus observasi dan analisis peneliti terletak pada periode kampanye, isi pesan, dan media yang digunakan oleh ketiga perguruan tinggi. Dengan mengacu pada model kampanye komunikasi kesehatan strategis, setidaknya ada empat tahapan yang akan dianalisis seperti yang tergambar pada bagan berikut:

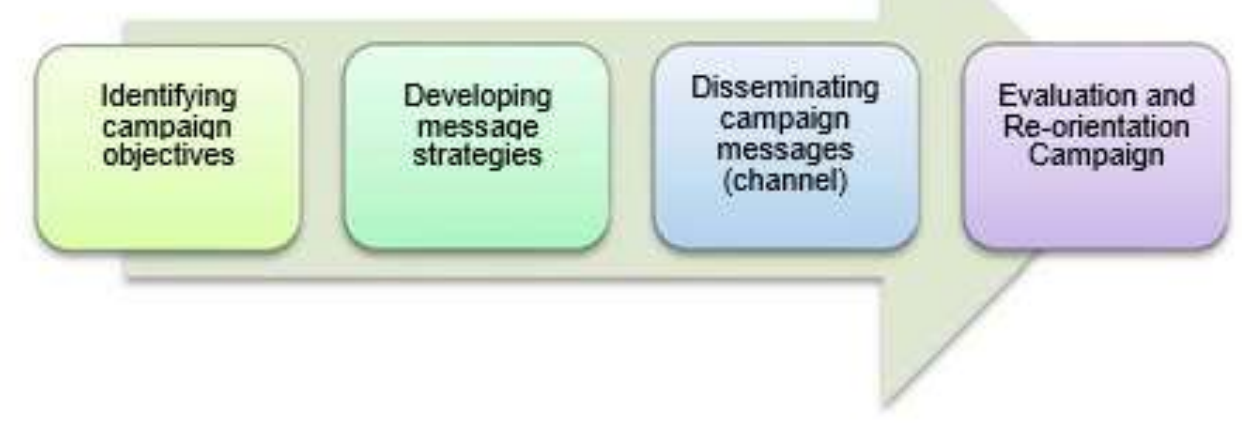

Gambar 1 Tahapan Model Kampanye Komunikasi Kesehatan Strategis (Sumber: Bonaguro dan Modifikasi Peneliti, 1993 \& 2021)

Setelah peneliti mengidentifikasi konten kampanye PHBS yang dimuat di akun resmi media sosial ketiga perguruan tinggi, tahapan selanjutnya yaitu menganalisis berdasarkan model kampanye MK3S, yang mana fokus analisis terletak pada periode kampanye, konstruksi pesan, 
dan dampak yang dirasakan oleh audiens. Teknik analisis data mengacu pada model interaktif yang memfokuskan pada tahapan kondensasi data, dimana peneliti harus menentukan mana data primer yang dianalisis dan data sekunder sebagai pelengkap untuk memperkuat analisis penelitian (Miles, 2009).

\section{I HASIL DAN PEMBAHASAN}

Komunikasi kesehatan merupakan bagian dari komunikasi manusia dengan fokus utama bagaimana individu menghadapi masalah kesehatan dan betapa pentingnya menjaga kesehatannya (Schiavo, 2007). Di masa pandemi COVID-19, komunikasi kesehatan dalam bentuk media kampanye digunakan untuk mengedukasi masalah kesehatan. Ada beberapa hal yang dibahas dalam kampanye tersebut, antara lain Germas (gerakan hidup sehat) di masa pandemi, pola hidup bersih dan sehat, cara menjaga kesehatan, dan cara menghadapi suatu penyakit. Komunikasi kesehatan juga termasuk komunikasi persuasif, karena dapat dilihat dari tujuannya untuk mempengaruhi dan mengajak khalayak untuk mengubah sikap dan perilakunya untuk hidup sehat (Berry, 2007; Rossi, \& Yudell, 2012; Schiavo, 2007). Dalam penelitian ini, peneliti memfokuskan pada analisis kampanye PHBS yang dilakukan oleh tiga perguruan tinggi di Kota Malang, yaitu Universitas Negeri Malang, Universitas Brawijaya, dan UIN Maliki Malang selama bulan Maret 2020 hingga Juni 2021 melalui akun resmi media sosial masing-masing universitas.

Beberapa hasil riset sebelumnya menyimpulkan bahwa pemilihan saluran komunikasi kampanye kesehatan melalui Internet dan media sosial dinilai berimplikasi pada adanya peningkatan pengetahuan terkait penyakit tertentu, menumbuhkan resiliensi ketika terjangkit virus, dan mendorong terjadinya perubahan perilaku (Al-Dmour et al., 2020; Situmenang, \& Situmenang, 2020). Begitu juga dengan fokus amatan dalam tulisan ini. Peneliti tertarik untuk melihat bagaimana praktik kampanye PHBS yang dilakukan oleh 3 perguruan tinggi di Kota Malang selama pandemi COVID-19. PHBS merupakan program pemerintah yang dikeluarkan oleh Departemen Kesehatan dengan Keputusan Menteri Kesehatan Republik Indonesia Nomor 1193/MENKES/SK/X/20041. PHBS penting untuk disosialisasikan karena menyangkut gaya hidup masyarakat. PHBS perlu disosialisasikan, disebarluaskan, dan didirikan di tempat-tempat yang banyak orang berkumpul. Kampanye PHBS merupakan program nasional yang terus ditingkatkan untuk mencapai derajat kesehatan masyarakat yang ideal. Adapun program-programnya, PHBS memiliki penyuluhan pola hidup sehat, pemberdayaan remaja, pembinaan sekolah sehat, dan terakhir pengembangan media sosialisasi kesadaran pola hidup sehat. Beberapa program lain bersinggungan dengan program kampanye PHBS bahkan mendukung pelaksanaan kampanye PHBS. PHBS merupakan manipulasi sosial yang bertujuan untuk mengubah sebanyak mungkin masyarakat menjadi agen perubahan yang dapat meningkatkan kualitas perilaku sehari-hari untuk hidup bersih dan sehat.

Definisi PHBS mengacu pada aktivitas perilaku kesehatan selama pandemi yang diawali dengan aktivitas $3 \mathrm{M}$ (mencuci tangan, memakai masker, menjaga jarak), beralih menjadi 5M dengan tambahan menghindari kerumunan dan membatasi mobilitas dan interaksi, dan terakhir per Juni 2021, aktivitas PHBS bertambah menjadi enam langkah antisipasi dengan tambahan "mengikuti vaksinasi". Harapannya, dengan adanya kampanye kesehatan PHBS melalui akun resmi Instagram dapat meningkatkan kesadaran dan kewaspadaan seluruh sivitas akademika terutama pada tiga perguruan tinggi yaitu Universitas Negeri Malang, Universitas Brawijaya, dan UIN Maliki Malang. Sehubungan dengan hal tersebut, berikut tampilan interface official account Instagram masingmasing perguruan tinggi: 


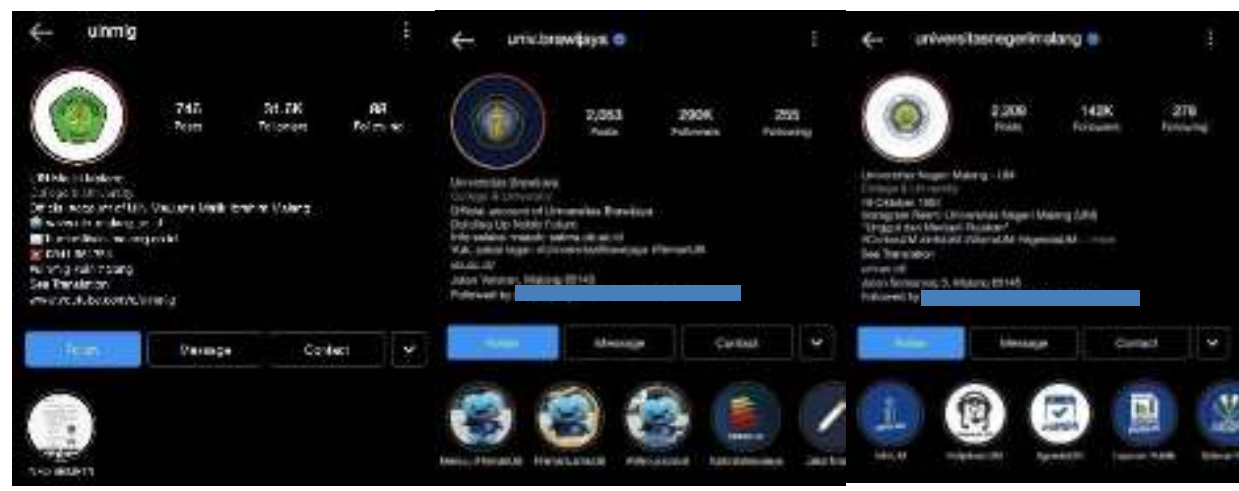

Gambar 2. Interface Official Account Instagram UM, UB, UIN Maliki Malang (Sumber: Dokumentasi peneliti, 2021)

Jika melihat ketiga akun resmi Instagram yang menjadi objek penelitian, akun Instagram milik Universitas Negeri Malang (@universitasnegerimalang) dan Universitas Brawijaya (@univ.brawijaya) sudah tercantum "centang biru” yang dapat diartikan bahwa akun tersebut telah dikonfirmasi atau diverifikasi (verified) oleh Instagram sebagai kehadiran otentik dari figur publik, merk global, dan institusi resmi. Namun demikian, walaupun akun Instagram milik UIN Mailiki Malang (@uinmlg) belum tercantum "centang biru” bukan berarti akun tersebut tidak asli, hanya saja membutuhkan waktu untuk diverifikasi oleh pihak Instagram. . Hingga riset ini diselesaikan pada bulan Agustus 2021, akun Instagram UIN Maliki akhirnya mendapatkan status "centang biru" dari pihak Instagram. alah satu keuntungan dengan status verified adalah informasi yang tersaji dapat dipilah secara otomatis mana yang fakta dan mana yang hoaks (fake news). Selain itu, dengan status verified secara tidak langsung memberikan efek pada tingkat kepercayaan dalam proses penerimaan pesan oleh audiens (Mena et al., 2020; Rebelo, 2017; Wielki, 2020). Memang seharusnya, untuk akun yang bersifat publik, seperti milik Universitas, sudah terverifikasi oleh Instagram agar media tersebut dapat dijadikan sumber referensi/acuan bagi sivitas akademika dan masyarakat umum.

Terdapat perbedaan fitur antara Instagram dengan media sosial lainnya seprti Facebook dan Twitter. Menurut engagement model, Instagram tidak menyediakan fitur berbagi langsung di platform, yang berbeda dengan Facebook dan Twitter. Hal ini dianggap sedikit memperlambat arus informasi yang diunggah di akun Instagram tersebut (Mena, Barbe, Chan-Olmsted, 2020). Namun, disisi lain, Instagram memiliki kelebihan yaitu memungkinkan pengguna untuk memantau langsung siapa saja user yang menyematkan liked atau menuliskan komentar atas unggahannya, meskipun di beberapa negara terdapat kebijakan untuk menghilangkan fitur liked dan komentar untuk menjaga kesehatan mental warga negara ketika menggunakan aplikasi ini (Leskin, 2019). Dengan demikian, dapat dikatakan bahwa sebaiknya untuk akun resmi media sosial milik institusi, seperti Universitas, sudah mendapatkan tanda centang biru (verified) dari pihak Instagram. Hal ini menjaga keabsahan informasi yang diunggah sehingga dapat mengurangi terjadinya infodemi bagi audiens.

Berdasarkan hasil observasi, dari ketiga akun resmi Instagram yang dimiliki oleh Universitas Negeri Malang, Universitas Brawijaya, dan UIN Maliki Malang dapat terlihat selain konsistensi unggahan pesan terkait COVID-19, juga bagaimana admin Instagram menjaga kredibilitas pesan yang diunggah, seperti misalnya menampilkan tangkapan layar Surat Edaran Rektor UM terkait Pengaturan Terbatas Aktivitas Kampus (PTAK) yang memang bersumber dari dokumen resmi dan asli yang dikeluarkan oleh pihak Universitas. Hal ini bertujuan untuk menjaga keaslian informasi, yang mana kontrol otensitas informasi tidak seketat di media massa konvensional. Sumber informasi sangat penting untuk kredibilitas karena adalah dasar utama yang menjadi dasar penilaian kredibilitas di media sosial (Metzger \& Flanagin, 2013). Sehingga dapat dikatakan bahwa status 
"centang biru" yang dimiliki oleh akun Instagram Universitas Negeri Malang dan Universitas Brawijaya memiliki potensi untuk memengaruhi penggunanya.

Sebelum menjelaskan secara rinci tahapan kampanye yang dilakukan oleh 3 perguruan tinggi yang dipilih dalam penelitian ini, peneliti akan menampilkan tabulasi frekuensi penyampaian informasi terkait COVID-19 di masing-masing akun Instagram resmi masing- masing universitas.

Tabel 1. Frekuensi tayang pesan official account IG pada 3 PT

\begin{tabular}{|c|c|c|}
\hline Nama Perguruan Tinggi & Frekuensi Tayang & Isi pesan yang ditampilkan \\
\hline Universitas & Oktober - November & Sosialisasi pencegahan penyebaran \\
\hline Negeri Malang & $\begin{array}{l}\text { 2020; Januari - Mei } \\
2021\end{array}$ & $\begin{array}{l}\text { COVID-19 melalui 3M, tata cara } \\
\text { membuang masker bekas pakai, } \\
\text { pengaturan kehadiran pegawai } \\
\text { dilingkungan UM, penerapan protokol } \\
\text { kesehatan } 5 \mathrm{M} \text {, sosialisasi Pengaturan } \\
\text { Terbatas Aktivitas Kampus (PTAK) dil } \\
\text { lingkungan UM, dan informasi layanan } \\
\text { vaksinasi bagi sivitas akademika UM }\end{array}$ \\
\hline Universitas & Maret - November & Sosialisasi penapisan COVID-19 secara \\
\hline Brawijaya & $\begin{array}{l}\text { 2020; Januari - Mei } \\
2021\end{array}$ & $\begin{array}{l}\text { online melalui aplikasi, informasi terkait } \\
\text { apa itu virus COVID-19, gejala, transmisi } \\
\text { penularan, dan pencegahan, informasi } \\
\text { terkait perkuliahan tahun akademik } \\
2021 / 2022 \text {, pesan motivasi dari Tim } \\
\text { Monefvas Kampus Tangguh UB, } \\
\text { informasi promosi kesehatan PHBS, } \\
\text { dan Surat Edaran Rektor tentang Masa } \\
\text { Respon (Skema Ketat) UB }\end{array}$ \\
\hline UIN Maliki Malang & Maret - Juni 2020 & $\begin{array}{l}\text { Surat Edaran tentang Kesiapsiagaan dan } \\
\text { Tindakan Antisipasi Pencegahan Infeksi } \\
\text { Virus COVID-19, kampanye pencegahan } \\
\text { penularan COVID-19 melalui tagline } \\
\text { "BISMILLAH" }\end{array}$ \\
\hline
\end{tabular}

Sumber: Hasil Olahan Peneliti, 2021

Berdasarkan tabel di atas, diketahui bahwa akun Instagram Universitas Brawijaya (@univ.brawijaya) telah mengunggah konten kampanye terkait COVID-19 sebanyak 15 kali, sedangkan Universitas Negeri Malang dengan nama akun @universitasnegerimalang mengunggah sebanyak 6 kali, dan terakhir akun UIN Maliki @uinmlg mengunggah sebanyak 2 kali dalam kurun waktu Maret 2020 hingga Juni 2021. Dari jumlah followers, dapat dilihat bahwa Instagram UB dengan memiliki followers sebanyak $306 \mathrm{~K}$, followers UM sebanyak $145 \mathrm{~K}$, dan jumlah followers UIN Maliki sebanyak 34.9K. Menariknya, adalah kampanye pencegahan penularan COVID-19 yang dilakukan oleh UIN Maliki Malang dengan tajuk "BISMILLAH" dengan penjelasan B (Berdiam diri di rumah); I (Istighfar kepada Allah atas segala dosa dan kesalahan); S (Social distancing / jaga jarak fisik); M (Mencuci tangan); I (lkuti maklumat dari pemerintah); L (Laporkan kepada Satgas jika demam/panas diatas 38 derajat); L (Laporkan kepada Satgas jika batuk mendera); A (Apalagi dari kota yang positif terjangkit Corona) dan $\mathrm{H}$ (Hanya kepada Allah kita berserah diri).

Selanjutnya, sesuai dengan Model Kampanye Komunikasi Kesehatan Strategis (MK3S) Bonaguro, hasil analisis terkait aktivitas kampanye PHBS masing-masing perguruan tinggi 
melalui akun resmi Instagram.

Tabel 2. Analisis Kampanye PHBS berbasis Model K3S Bonaguro

\begin{tabular}{|c|c|c|c|c|}
\hline $\begin{array}{c}\text { Perguruan } \\
\text { Tinggi }\end{array}$ & $\begin{array}{l}\text { Identifying } \\
\text { campaign } \\
\text { objectives } \\
\text { (1) }\end{array}$ & $\begin{array}{c}\text { Developing } \\
\text { message } \\
\text { strategies } \\
\text { (2) }\end{array}$ & $\begin{array}{c}\text { Disseminating } \\
\text { campaign } \\
\text { messages } \\
\text { (channel) } \\
\text { (3) }\end{array}$ & $\begin{array}{l}\text { Evaluation and } \\
\text { Reorientation } \\
\text { Campaign } \\
\text { (4) }\end{array}$ \\
\hline $\begin{array}{l}\text { Universitas } \\
\text { Negeri } \\
\text { Malang }\end{array}$ & $\begin{array}{l}\text { Menginformasikan } \\
\text { publik (sivitas } \\
\text { akademika) UM } \\
\text { terkait COVID-19 } \\
\text { meliputi informasi } \\
\text { gejala, transmisi } \\
\text { penularan, dan } \\
\text { strategi } \\
\text { pencegahan } \\
\text { 3M dan 5M }\end{array}$ & $\begin{array}{l}\text { Strategi } \\
\text { perancangan } \\
\text { pesan menonjolkan } \\
\text { informasi umum } \\
\text { COVID-19 desain } \\
\text { dominan warna } \\
\text { biru. Proses } \\
\text { perancangan } \\
\text { dilakukan Humas } \\
\text { Universitas } \\
\text { bekerjasama } \\
\text { dengan Satgas } \\
\text { COVID-19 UM }\end{array}$ & $\begin{array}{l}\text { Akun IG } \\
\text { sejak Oktober } \\
2020-M e i \text { 2021. } \\
\text { Diseminasi } \\
\text { kampanye } \\
\text { PHBS lebih } \\
\text { banyak } \\
\text { dilakukan } \\
\text { melalui } \\
\text { IG dan WA } \\
\text { Status dari } \\
\text { sivitas } \\
\text { akademika UM }\end{array}$ & $\begin{array}{l}\text { Konsistensi isi } \\
\text { pesan dominan } \\
\text { surat edaran } \\
\text { Rektor pembatasan } \\
\text { aktivitas kampus, } \\
\text { informasi PHBS } \\
\text { tidak muncul di IG } \\
\text { sejak Januari } \\
2021\end{array}$ \\
\hline $\begin{array}{l}\text { Universitas } \\
\text { Brawijaya }\end{array}$ & $\begin{array}{l}\text { Tujuan kampanye } \\
\text { menginformasikan } \\
\text { terkait COVID-19 } \\
\text { pesan edukatif } \\
\text { penerapan } \\
\text { protokol } \\
\text { kesehatan dan } \\
\text { pembatasan } \\
\text { aktivitas di UB }\end{array}$ & $\begin{array}{l}\text { Perancangan pesan } \\
\text { dilakukan humas } \\
\text { universitas } \\
\text { berkoordinasi } \\
\text { tim monevfas } \\
\text { Kampus Tangguh } \\
\text { UB }\end{array}$ & $\begin{array}{l}\text { Pemilihan } \\
\text { saluran/media } \\
\text { yaitu melalui } \\
\text { media sosial } \\
\text { (Instagram) } \\
\text { dan rilis media } \\
\text { massa online }\end{array}$ & $\begin{array}{l}\text { Konsistensi } \\
\text { pesan } \\
\text { belum } \\
\text { tampak } \\
\text { memberikan } \\
\text { edukasi PHBS, } \\
\text { masih seputar virus }\end{array}$ \\
\hline $\begin{array}{l}\text { UIN Maliki } \\
\text { Malang }\end{array}$ & $\begin{array}{l}\text { Tujuan kampanye } \\
\text { menginformasikan } \\
\text { terkait virus } \\
\text { COVID-19 dan } \\
\text { belum tampak } \\
\text { menjelaskan } \\
\text { tentang PHBS }\end{array}$ & Admin IG & $\begin{array}{l}\text { Media Yang } \\
\text { dipilih }\end{array}$ & $\begin{array}{l}\text { COVID-19-vaksinasi } \\
\text { tidak pernah } \\
\text { dievaluasi. } \\
\text { Konsistensi } \\
\text { unggahan } \\
\text { yang hanya } \\
\text { berlangsung } \\
\text { singkat, } \\
\text { yaitu bulan } \\
\text { Maret } \\
\text { hingga Juni } \\
2020 \text { saja. }\end{array}$ \\
\hline
\end{tabular}

Sumber: Hasil Olahan Peneliti, 2021

\section{4 | SIMPULAN DAN SARAN}

Berdasarkan hasil analisis data yang telah diolah sejak bulan Juli - September 2021, peneliti menyimpulkan bahwa aktivitas kampanye komunikasi tentang Perilaku Hidup Bersih dan Sehat (PHBS) melalui akun resmi Instagram ketiga perguruan tinggi belum tampak konsisten, khususnya dari aspek perancangan pesan dan penggunaan saluran/media (channel). Universitas Negeri Malang lebih intens untuk mengunggah informasi terkait prestasi mahasiswa dan aktivitas kampus, dibanding 
mengunggah secara berkala informasi pencegahan penularan COVID-19 di lingkungan kampus. Sedangkan Universitas Brawijaya terbilang cukup aktif mengunggah informasi seputar COVID-19 disertai dengan interaksi dan bahkan engagement antara admin Instagram dengan followers (pengikut) dan user (pengguna). Terakhir, UIN Maliki tergolong cukup rendah, dengan jumlah unggahan sebanyak 6 kali terkait COVID-19. Meskipun UIN Maliki sempat merilis kampanye bertajuk BISMILLAH yang diklaim sebagai kampanye pecegahan tertular dari COVID-19. Dapat disimpulkan bahwa, masing-masing perguruan tinggi menampilkan pesan yang umum terkait virus COVID-19, hanya unggahan dari Universitas Brawijaya yang memberikan edukasi terkait protokol kesehatan dan itupun sebanyak 2 kali. Penelitian ini masih terbatas dari analisis teks atas unggahan yang bersumber dari akun resmi media sosial Instagram milik perguruan tinggi di Malang, belum menyentuh pada aspek resepsi audiens atas konten informasi kampanye pencegahan penularan COVID-19 melalui aktivitas Perilaku Hidup Bersih dan Sehat (PHBS). Diharapkan setelah hasil riset ini terbit muncul penelitian sejenis untuk memperkaya publikasi penelitian terkait COVID-19, terutama untuk model kampanye komunikasi kesehatan.

\section{REFERENS I}

Al-Dmour, H., Masa'deh, R., Salman, A., Abuhashesh, M., \& Al-Dmour, R. (2020). Influence of Social Media Platforms on Public Health Protection Against the COVID-19 Pandemic via the Mediating Effects of Public Health Awareness and Behavioral Changes: Integrated Model. Journal of Medical Internet Research, 20(8), 8-20.

Aprillia, I. (2021, June 21). Temuan LIPI, Covid-19 Varian Delta Sudah Masuk Jabar via Karawang, Warga Diimbau di Rumah Saja. Kompas.Com, 21.

https://regional.kompas.com/read/2021/06/21/072641178/temuan-lipi-covid-19-varian-deltasudah-masuk-jabar-via-karawang-warga?page=all

Asharo, R. K., Arifiyanto, A., Khaleyla, F., \& Rahmadi, C. T. (2021). Wawasan Perilaku Hidup Bersih dan Sehat (PHBS) di Masa Kenormalan Baru dalam Upaya Mencegah Penyebaran Covid-19 di Lingkungan Sekolah. Mitra Mahajana: Jurnal Pengabdian Masyarakat, 2(2), 184192.

Berry, D. (2007). Health communication: Theory and practice. Open University Press.

Binnendijk, A. (1996). A.I.D.'s experience with contraceptive social marketing: a synthesis ofproject evaluation findings. USAID. www.pdf.usaid.gov/pdf_docs/\%0APNAAL073.pdf.

Cheng, H., Kotler, P., \& Lee, N. (2011). Social marketing for public health: global trends and success stories. Jones and Bartlett.

Department of Health and Human Services. (2014). Best practices for comprehensive tobacco control programs.

Faisal, S. (2003). Format-format penelitian sosial. PT RajaGrafindo Persada.

Medicine), I. (Institute of. (2002). Speaking of health: assessing health communication strategies for diverse populations. National Academic Press.

Mena, P., Barbe, D., \& Chan-Olmsted, S. (2020, April). Misinformation on instagram: The impact of trusted endorsements on message credibility. Social Media + Society, 1-9.

Mendelsohn, H. (1976). Mass communication and cancer control. In J. Cullen, B. Fox, \& I. RN (Eds.), Cancer: the behavioral dimensions. Raven.

Miles, M. B. \& A. M. H. (2009). Analisis Data Kualitatif. UI-Press.

Muliati, N. K. (2020). Pengaruh Perekonomian Indonesia di Berbagai Sektor Akibat Corona Virus Disease 2019 (Covid-19). Widya Akuntansi Dan Keuangan, 2(2), 78-86.

Nalini, S. N. L. (2021). Dampak Dampak covid-19 terhadap Usaha Mlkro, Kecil dan Menengah. Jesya (Jurnal Ekonomi Dan Ekonomi Syariah), 4(1), 662-669. 
$\mathrm{NCl}$. (2008). The role of the media in promoting and reducing tobacco use.

Rebelo, M. (2017). How influencers' credibility on instagram is perceived by consumers and its impact on purchase intention. Universidade Catolica Portugesa.

Rizal, J. G. (2020, August 11). Pandemi Covid-19, Apa Saja Dampak pada Sektor Ketenagakerjaan Indonesia? Kompas. Com, 13. https://www.kompas.com/tren/read/2020/08/11/102500165/pandemi-covid-19-apa-sajadampak-pada-sektor-ketenagakerjaan-indonesia-?page=all

Rokhaniyah, S., \& Sinta, S. (2021). Penguatan Ketahanan Masyarakat di Era Pandemi Covid-19. Journal of Community Development, 1(2), 71-77.

Rossi, J., \& Yudell, M. (2012). The use of persuasion in public health communication: An ethical critique. Public Health Ethics, 5.

Sari, M. T., Putri, M. E., Daryanto, D., \& Yanti, E. (2021). EDUKASI DAN KAMPANYE KESEHATAN PERILAKU HIDUP BERSIH DAN SEHAT (PHBS) DI ERA PANDEMI COVID19 BAGI ANAK PANTI ASUHAN. Jurnal Abdimas Saintika, 3(1), 30-34. https://doi.org/http://dx.doi.org/10.30633/jas.v3i1.1078 Article Metrics

Schiavo, R. (2007). Health communication: from theory to practice. John Wiley\& Sons, Inc.

Setiyaningsih, L. A., \& Jatmikowati, S. H. (2019). Media Baru Dalam Komodifikasi Waktu Luang Ibu Rumah Tangga. ETTISAL: Journal of Communication, 4(1), 23-32.

Setiyaningsih, L. A. (2017). KORELASI TERPAAN MEDIA KIE (KOMUNIKASI, INFORMASI DAN EDUKASI) PENANGGULANGAN HIV DAN AIDS DENGAN TINGKAT PENGETAHUAN PEKERJA SEKS PEREMPUAN (Studi Kasus Pekerja Seks Perempuan Kabupaten Malang). Jurnal Nomosleca, 3(1), 551-567. https://doi.org/10.26905/nomosleca.v3i1.1484

Setiyaningsih, L. A. (2020). MEDIA PANICS IBU RUMAH TANGGA SETELAH MENGAKSES BERITA COVID-19 (2020). Jurnal Nomosleca, 6(2), 101-110. http://jurnal.unmer.ac.id/index.php/n/article/view/4721/2594

Situmenang, I. V. ., \& Situmenang, I. . (2020). Konstruksi komodifikasi media komunikasi untuk kampanye sosial di Instagram dalam pencegahan virus corona pada new era masyarakat 5.0. COMMED: Jurnal Komunikasi Dan Media, 5(1), 34-53.

Sugiyono. (2017). Metode Penelitian Kuantitatif, Kualitatif, dan R\&D. CV. Alfabeta.

Suminar, S., \& Islami, L. (2021). PERAN PROJECT LEADER UNTUK PERSUASIF REMAJA DALAM MASA PANDEMI MELALUI KAMPANYE CREATIVE YOUTH COOKPAD INDONESIA HIDUP SEHAT\# DIRUMAHAJA. PANTAREI, 5(1).

Supanji, T. H. (2021, March 24). Pemerintah Optimalkan Hasil Survei Dampak Pandemi Covid-19 dan Pemulihan Ekonomi Penyandang Disabilitas. Kemenkopmk, 3.

https://www.kemenkopmk.go.id/pemerintah-optimalkan-hasil-survei-dampak-pandemi-covid19-dan-pemulihan-ekonomi-penyandang

Triono, M. A., \& Setiyaningsih, L. A. (2017). Desain Disonansi Kognitif Sebagai Faktor Anteseden Untuk Penguatan Kualitas Informasi Pada Website. Seminar Nasional Sistem Informasi, 1(1), 71-79. http://eprints.unmer.ac.id

Wielki, J. (2020). Analysis of the role of digital influencers and their impact on the functioning of the contemporary on-line promotional system and its sustainable development. Sustainability, MDPI, 12(7138), 1-20. 